\title{
The annual life history of a population of the aquatic Coleopteran Derallus angustus (Coleoptera: Hydrophilidae)
}

\author{
Liliana Alicia Fernández \\ División Entomología del Museo de La Plata. Paseo del Bosque, La Plata, 1900, Argentina; \\ liliafer@museo.fcnym.unlp.edu.ar \\ Received 17-VII-2006. Corrected 14-III-2007. Accepted 22-X-2007.
}

\begin{abstract}
Derallus Sharp, 1882 is a Neotropical genus of aquatic coleopterans that belongs in the tribe Berosini and includes 15 species. D. angustus Sharp is widely distributed from Guatemala to Argentina. The population dynamics of this species was studied by periodic sampling of a natural population from the southernmost Subtropical Domain of the Neotropical Region. The study site was near Punta Lara $\left(34^{\circ} 47^{\prime} \mathrm{S}, 58^{\circ} 01^{\prime}\right.$ W; Ensenada, Buenos Aires province, Argentina). Twenty seven samples consisting of 20 units of aquatic vegetation (200 $\mathrm{cm}^{2}$ each) were taken during one year. Larvae and adults were removed from the vegetation and counted (pupae were not studied). There was a peak of first instar larvae abundance at the end of spring, and another at the end of summer. Adults and third instar larvae were present throughout the whole year. The population is interpreted as being univoltine and including two periods of enhanced reproductive activity. Rev. Biol. Trop. 56 (1): 345-348. Epub 2008 March 31.
\end{abstract}

Key words: aquatic insects, Hydrophilidae, Derallus angustus, population dynamics, Argentina.

Derallus is a neotropical genus of the tribe Berosini and includes 15 species of aquatic coleopterans (Oliva 1981, 1983, 1995, Oliva et al. 1998, Hansen 1999). D. angustus Sharp is widely distributed from Guatemala to Argentina, and in the last country it has been recorded in Salta, Formosa, Chaco, Santa Fe, Corrientes, Entre Ríos, and Buenos Aires provinces (Fernández and Bachmann 1998). This species inhabit lentic environments covered by aquatic plants through which larvae and adults slowly moves.

Larval descriptions of this genera are scarce. Spangler (1966) carried out the first, on larvae of Derallus rudis Sharp ,1887. Later, Archangelsky and Durand (1992) described all the preimaginal stages of D. angustus. Recently, Archangelsky and Fernández (2005) described the larvae of $D$. paranensis Oliva, 1981. No population studies have been carried out yet. The purpose of this research was to study the population dynamics of this species by periodic sampling of a natural population from the southernmost Subtropical Domain of the Neotropical Region (Cabrera and Willink 1980).

\section{MATERIALS AND METHODS}

The study site was a permanent water body, located near Punta Lara $\left(34^{\circ} 47^{\prime} \mathrm{S}\right.$, $58^{\circ} 01^{\prime} \mathrm{W}$; Ensenada, Buenos Aires Province, Argentina). This area represents the southern end of a "gallery forest" and has a subtropical and tropical floristic composition. The water level in the selected pond is partially influenced by the tides of the Río de La Plata river, which is approximately $200 \mathrm{~m}$ from it. During the sampling period the water body was covered by Salvinia rotundifolia Wild., which was observed during the whole year, Pistia stratiotes L., Spirodela intermedia W. Koch, 
Lemna sp. and Hydrocotyle ranunculoides L. Twenty seven samples (approximately two per month) were taken from April 1989 to April 1990. On each sample date 20 random sample units of $200 \mathrm{~cm}^{2}$ aquatic vegetation were taken with a strainer, between 10:30 and 11:30 AM. Each vegetation unit was spread separately on Berlese-Tullgren funnels in laboratory, and specimens were collected after $48 \mathrm{~h}$. Larvae and adults were maintained in $70 \%$ ethyl alcohol for subsequent identification and counting. Pupae were not included in this research as it would have been necessary to undertake a different methodological approach.

Temperature and rainfall data during the sampling period was provided by the "Estación Meteorológica La Plata, Facultad de Ciencias Astronómicas y Geofísicas, Universidad Nacional de La Plata". A Pearson Product Moment Correlation test was done between monthly mean temperature and rainfall and population data (adults and larvae).

\section{RESULTS}

Average monthly temperature and rainfall are shown in Fig. 1. Two well defined peaks of first instar larvae maximum abundance were recognized: the first one at the end of spring and the second one at the end of summer (Fig. 2). This larval stage was not recorded from June to November. Adults and third instar larvae were present throughout the whole year. Concerning the larvae III, the highest abundance was reached in March-April (fall). Larvae II was not recorded neither in September nor in November.

Adults and larvae II and III were neither significantly correlated with month mean temperature nor with month mean rainfall. Only larvae I was significantly correlated with month mean temperature $(r=0.688, p<0.05)$ and with month mean rainfall $(\mathrm{r}=0.607, \mathrm{p}<0.05)$.

\section{DISCUSSION}

The greatest number of adults was observed in October (spring), probably because of the emergence of new adults from immature stages recorded in winter. The minimum number of adults was recorded in late spring, probably as consequence of enhanced mortality after egg laying. According to the observed abundances, the breeding period begins in early November

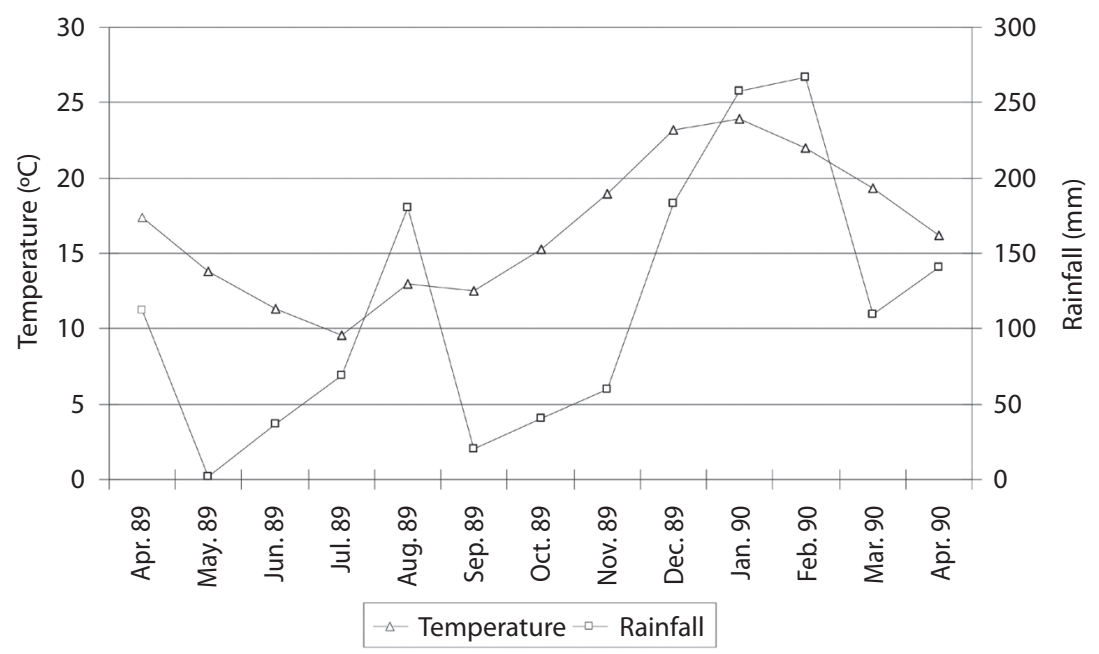

Fig. 1. Average monthly temperature and rainfall from April 1989 to April 1990 (data from "Estación Meteorológica La Plata, Facultad de Ciencias Astronómicas y Geofísicas, Universidad Nacional de La Plata”). 


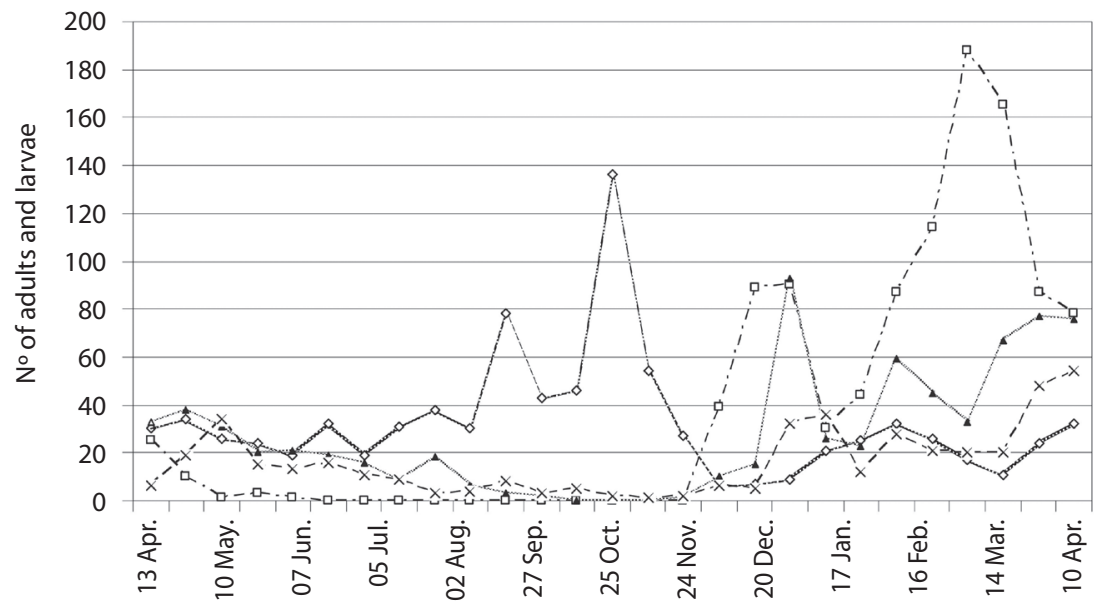

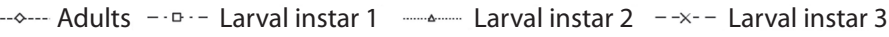

Fig. 2. Seasonal fluctuations of Derallus angustus.

(middle spring). In January, the slight increase in the number of adults, might be a result of a new generation. These adults may remain active during winter and would lay egg during the next spring.

Some laboratory data on the biology of this species were reported by Archangelsky and Durand (1992). Notoworthily, the highest mortality occurs at the prepupal and pupal stages. There is no pupation chamber or any other protection for the pupa and it remains completely exposed on the leaf surface of Salvinia sp. (Archangelsky and Durand 1992). The fact that this population remains active throughout the whole year could be due to the environmental conditions, considering that its habitat belongs to a relatively stable microclimate within the "gallery forest", in contrast to the nearby environments of the pampasic grasslands. D. angustus has only been found as stable population in a "gallery forest" permanent pond with a dense carpet of floating Salvinia sp. (von Ellenrieder and Fernández 2000).

The life cycle could therefore be assumed to be annual. The population is interpreted as univoltine including two periods of enhanced reproductive activity.

\section{ACKNOWLEDGMENTS}

We thank A. Rodrígues Capítulo for the critical review of the manuscript. This paper is the scientific contribution $\mathrm{n}^{\circ} 803$ of the Instituto de Limnología "Dr. Raúl A. Ringuelet". This study was supported by the National Research Council of Argentine (CONICET).

\section{RESUMEN}

Derallus Sharp, 1882, de distribución Neotropical, pertenece a la tribu Berosini y está representado por 15 especies. D. angustus Sharp está ampliamente distribuida desde Guatemala hasta Argentina. El objetivo de este trabajo es el estudio de la dinámica poblacional de esta especie, en un limnótopo ubicado en el extremo sur del Dominio Subtropical de la Región Neotropical. El sitio de muestreo está localizado en Punta Lara (344ㄱ' S, $58^{\circ} 01^{\prime} \mathrm{W}$, Ensenada, Buenos Aires Province, Argentina). Se realizaron 27 muestreos durante un período de un año, cada uno consistió en la extracción de 20 muestras al azar de $200 \mathrm{~cm}^{2}$ de vegetación flotante. El estado de pupa no fue incluido en este estudio. Se reconocieron dos picos de máxima abundancia del primer estadio larval (el primero a fines de primavera y el otro a fines del verano). Durante todo el período de estudio se registraron tanto adultos como 
larvas de tercer estadio. Se interpreta que la población es univoltina con dos períodos de actividad reproductiva.

Palabras clave: insectos acuáticos, Hydrophilidae, Derallus angustus, dinámica poblacional, Argentina.

\section{REFERENCES}

Archangelsky, M. \& M. Durand. 1992. Description of the preimaginal stages of Derallus angustus Sharp, 1882 (Coleoptera: Hydrophilidae, Berosinae). Aquat. Ins. 14: 169-178.

Archangelsky, M. \& L.A. Fernández. 2005. Description of new Neotropical Berosini larvae: Derallus paranensis and Hemiosus dejeanii (Coleoptera: Hydrophilidae). Coleopts. Bull. 59: 211-220.

Cabrera, A. \& A. Willink. 1980. Biogeografía de América Latina. Secretaría General de la OEA, Serie de Biología, Washington D.C., USA.

Fernández, L.A. \& A.O. Bachmann. 1998. Hydrophiloidea, p. 218-226. In Biodiversidad de artrópodos argentinos: una perspectiva biotaxonómica. J.J. Morrone \& S. Coscarón (eds.). Ediciones Sur, La Plata, Argentina.
Hansen, M. 1999. World Catalogue of Insects. Hydrophiloidea (Coleoptera), Vol. 2. Apollo, Stenstrup, Denmark.

Oliva, A. 1981. El género Derallus Sharp en la Argentina (Coleoptera, Hydrophilidae). Rev. Soc. Entom. Argent. 40: 285-296.

Oliva, A. 1983. Derallus de la cuenca del Amazonas (Coleoptera, Hydrophilidae). Rev. Soc. Entom. Argent. 42: 343-351.

Oliva, A. 1995. Novedades sobre Derallus (Coleoptera, Hydrophilidae). Physis Secc. B, 50: 1-3.

Oliva, A., L.A. Fernández \& A.O. Bachmann. 1998. Sinopsis de los Hydrophiloidea acuáticos de la Argentina (Insecta, Coleoptera). Monografías del Museo Argentino de Ciencias Naturales 2: 1- 67.

Spangler, P. 1966. A description of the larva of Derallus rudis Sharp (Coleoptera: Hydrophilidae). Coleopts. Bull. 20: 97-103.

von Ellenrieder N. \& L.A. Fernández. 2000. Aquatic Coleoptera in the Subtropical-Pampasic ecotone (Argentina, Buenos Aires): species composition and temporal changes. Coleopts. Bull. 54: 23-35. 